\title{
Synthesis, characterization and cytotoxicity of Chitosan/Polyvinyl Alcohol/Bioactive Glass hybrid scaffolds obtained by lyophilization
}

\author{
Alexandra Rodrigues Pereira da Silva ${ }^{1}$, Tais Lício Macedo ${ }^{1}$, \\ Dante Jesús Coletta $^{2}$, Sara Feldman ${ }^{2}$, Marivalda de Magalhães Pereira ${ }^{1}$
}

\footnotetext{
${ }^{1}$ Laboratório de Biomateriais, Departamento de Engenharia Metalúrgica e de Materiais, Universidade Federal de Minas Gerais, Belo Horizonte, Minas Gerais, Brasil.

e-mail: mpereira@demet.ufmg.br

${ }^{2}$ Laboratório de Biología Osteoarticular, Ingeniería Tisular y Terapias Emergentes, Facultad de Ciencias Médicas, Universidad Nacional de Rosário, Argentina.
}

\begin{abstract}
One of the important research topics in tissue engineering is the development of optimum three-dimensional scaffolds for regeneration and growth of bone tissue. The scaffold developed should promote an initial biomechanical support, provide the formation, deposition and organization of the new organic matrix generated, and degrade proportionally to the growth of the new tissue. In this study hybrid scaffolds based on the blend Chitosan (CHI)/Poly (vinyl alcohol) (PVA), with two different CHI:PVA molar ratios (1:1, and 3:1), and Bioactive Glass as the inorganic phase, were developed by a sol-gel route, followed by lyophilization. The materials were cross-linked with Glutaraldehyde. The obtained porous scaffolds were characterized by SEM, FTIR, porosity measurements by Archimedes method, and compression test. The in vitro degradation was studied by immersion in simulated body fluid for several time periods and evaluation of mass loss. Citotoxicity analysis was carried out on samples as prepared and after immersion in PBS solution for 24hrs, using human fibroblast cells and MTT method to evaluate cell viability. The matrices obtained showed promising results, presenting about $96 \%$ porosity, pore size varying in the range $20-300 \mu \mathrm{m}$, and interconnected pores. The mass loss presented by the matrices with CHI/PVA ratios 3:1 and 1:1 during the degradation test in vitro, was around $10 \%$ after a week of testing, with macroscopic preservation of their physical structure. Cytotoxicity tests showed that the samples were toxic as produced and not toxic after treatment with PBS, showing this approach was suitable as a final preparation step of these samples.
\end{abstract}

Keywords: Chitosan, PVA, bioactive glass, lyophilization, porosity, scaffolds

\section{INTRODUCTION}

Synthetic three-dimensional matrices are currently widely studied for application in the regeneration of bone tissue by presenting architecture similar to bone extracellular matrix and providing a suitable microenvironment for cell adhesion, proliferation and differentiation, ensuring tissue growth inside [1,2]. Among other properties, these scaffolds should exhibit biocompatibility with the damaged tissue, interconnected network of pores, pore size range from 100 to $300 \mu \mathrm{m}$, mechanical strength similar to bone tissue, and biodegradability at the rate which the tissue regenerates $[3,4]$. The production of nanocomposites based on biodegradable polymers and bioactive glasses has been the focus of extensive studies in the literature [5, 6], aiming at obtaining scaffolds with the described characteristics.

Bioactive glasses in the system $\mathrm{SiO}_{2}-\mathrm{CaO}-\mathrm{P}_{2} \mathrm{O}_{5}$ have been investigated as biomaterials to be introduced into the organic phase due to their osteoconductive and osteoinductive properties [7, 8]. When implanted in the human body, the formation of a layer of carbonated hydroxyapatite (HCA) occurs on the surface of the bioactive glass, responsible for the interfacial bonding of the implant to the tissue. However, its fragility and low mechanical strength limit its clinical applications. Mechanical properties of porous scaffolds are crucial, especially with regard to the regeneration of hard tissue such as bone, which must support a load and meet specific mechanical needs while stimulating bone regeneration. Pure bioactive glass scaffolds, with 
high porosity around $90 \%$, although inducing a biological response that stimulates bone regeneration [9], are fragile and have such a low resistance that makes it difficult even to handle the material. An alternative approach is the production of composites and hybrid systems [10-13].

Chitosan has been widely studied for bone tissue engineering because it is biocompatible, biodegradable, and also favors osteoconduction $[14,15]$. However this natural polymer presents relatively low strength and low flexibility. Despite its tremendous promise in bone tissue engineering application, the poor mechanical properties of chitosan limits its clinical application in weight bearing bones, which has been addressed by the addition of bioceramics in chitosan scaffolds [16-19]. The mechanical properties of the organic matrix can be improved further by mixing Chitosan with another polymer and by crosslinking [18-19].

In previous work, LEMOS et al [20] investigated the production of Bioactive Glass/Chitosan hybrid films, with various contents of the inorganic phase, using a sol-gel route. The hybrid films obtained exhibited high tensile strength, high bioactivity and cell viability. It was shown that the optimal concentration of added bioactive glass was $20 \%(\mathrm{w} / \mathrm{w})$. This study investigates Chitosan/PVA hybrids containing $20 \%$ of bioactive glass $(\mathrm{w} / \mathrm{w})$, with two different Chitosan:PVA mass ratios (3:1: and 1:1). The use of a polymeric blend is proposed in this work, based on the results obtained by Costa-Junior et al [21-23], which showed that the flexibility of chitosan is increased by addition of PVA. The materials were synthesized by the sol-gel route, crosslinked with glutaraldehyde, and dried by lyophilization to produce a porous scaffold. This technique, also known as freeze-drying, is widely used to create biomaterials with high porosity and complex hierarchical architecture [24, 25].

\section{MATERIALS AND METHODS}

\subsection{Synthesis of three-dimensional scaffolds}

\subsubsection{Preparation of Polymer and Bioactive Glass Precursor Solutions}

All reagents were supplied by Aldrich Chemical.

Poly (vinyl alcohol) (PVA) solution $5.0 \%(\mathrm{w} / \mathrm{v})$ was prepared by dissolving PVA (80\% degree of hydrolysis $)$ in deionized water $(100 \mathrm{~mL})$ under mechanical stirring at $70^{\circ} \mathrm{C}\left( \pm 2^{\circ} \mathrm{C}\right)$ for 45 minutes.

A solution of Chitosan (CHI) with high molecular weight and degree of deacetylation (DD) $>75 \%$ $(1 \% \mathrm{w} / \mathrm{v})$ was prepared by dissolving $1 \mathrm{~g}$ of commercial powder in $100 \mathrm{ml}$ of deionized water. $2 \mathrm{ml}$ of acetic acid was added to the solution, and then subjected to mechanical stirring for 24 hours.

Bioactive glass $60 \mathrm{~S}$ precursor solution $(\mathrm{BG})$ was obtained by acid hydrolysis and polycondensation of Tetraethylorthosilicate (TEOS - $\left.\left(\mathrm{Si}\left(\mathrm{OC}_{2} \mathrm{H}_{5}\right)_{4}\right)\right)$, alkoxide precursor of $\mathrm{SiO}_{2}$, and Triethylphosphate (TEP $\left.\left(\left(\mathrm{C}_{2} \mathrm{H}_{5} \mathrm{O}\right)_{3} \mathrm{PO}\right)\right)$, alkoxide precursor $\mathrm{P}_{2} \mathrm{O}_{5}$. Hydrolysis occurred by adding deionized water and nitric acid as catalyst reagent. Calcium Nitrate $\left(\mathrm{Ca}\left(\mathrm{NO}_{3}\right)_{2} \cdot 4 \mathrm{H}_{2} \mathrm{O}\right)$ was then added as a precursor of $\mathrm{CaO}$. The nominal composition of the bioactive glass was: $60 \% \mathrm{SiO}_{2}, 36 \% \mathrm{CaO} ; 4 \% \mathrm{P}_{2} \mathrm{O}_{5}$.

Glutaraldehyde solution $(2.0 \% \mathrm{w} / \mathrm{v})$ was prepared by diluting $25 \%$ glutaraldehyde $2 \mathrm{ml}$ in $23 \mathrm{~mL}$ of deionized water.

\subsubsection{Scaffolds Production}

The scaffolds were fabricated by mixing PVA solution with Chitosan solution in the ratios of CHI:PVA 3:1 and 1:1 in accordance with Table 1, and mixing under agitation for 30 minutes. The precursor solution of bioactive glass ( $20 \%$ of the total weight of the scaffold) was added and mechanical stirring was continued for 45 minutes. Finally, the solution of glutaraldehyde $2 \%$ (3\% of polymer mass) was added and mechanical stirring remained for 15 minutes.

Table 1: Composition of scaffolds.

\begin{tabular}{c|c|c|c|c}
\hline \multirow{2}{*}{ Scaffold CHI:PVA ratio } & \multicolumn{5}{|c}{ Composition (\%) } \\
\cline { 2 - 5 } & Chitosan & PVA & VB & Glutaraldehyde $^{*}$ \\
\hline $3: 1$ & 60 & 20 & 20 & 3 \\
\hline $1: 1$ & 40 & 40 & 20 & 3 \\
\hline$*$ In relation to polymers mass
\end{tabular}


The resulting solution was poured into vials of $7 \mathrm{~mL}$ with a syringe and kept at room temperature for 72 hours, the time required for gelation to occur. The vials were kept closed during gelation. The vials were then frozen for 72 hours in a refrigerator at $-20^{\circ} \mathrm{C}$.

The frozen vials were immersed in liquid nitrogen for 20 minutes and then placed on the lyophilizer (Model: K105 - Company Liotop - SP/Brazil) for $48 \mathrm{~h}$ with $-98^{\circ} \mathrm{C}$ condenser temperature and $-4^{\circ} \mathrm{C}$ sample collector temperature. The pressure in the collector was $30 \mathrm{mmHg}$.

\subsection{Characterization of three-dimensional scaffolds}

\subsubsection{Scanning Electron Microscopy}

The scaffolds were characterized by Scanning Electron Microscopy (SEM) FEI-Inspect-S50/Czech Republic. The samples were immersed in liquid nitrogen and fractured to obtain the internal fracture surface for analysis, which was then coated with gold.

\subsubsection{Fourier Transform Infrared Spectroscopy-ATR}

The scaffolds were characterized by Fourier Transform Infrared Spectroscopy (FTIR) by ATR mode (attenuated total reflectance) the wave number range $4000-500 \mathrm{~cm}^{-1}$ at a resolution of $1 \mathrm{~cm}^{-1}$ with an average of 64 scans, the equipment used was the Nicolet 380 ThermoScientific.

\subsubsection{Porosity - Method of Archimedes}

The mass of dried samples $\left(\mathrm{m}_{\mathrm{dr}}\right)$, saturated with fluid $\left(\mathrm{m}_{\mathrm{sa}}\right)$ and suspended in the fluid $\left(\mathrm{m}_{\mathrm{fl}}\right)$ were measured six times. Five hybrid samples of each type with $18 \mathrm{~mm}$ x $9 \mathrm{~mm}$ were used. Deionized water (density of $\left.0.9982 \mathrm{~g} / \mathrm{cm}^{3}\right)$ was used as fluid. The volume density $\left(\rho_{\mathrm{vol}}\right)$ was calculated using Equation 1, and the true density $\left(\rho_{\text {tr }}\right)$ was estimated through Equation 2. Apparent porosity was calculated by Equation 3 and finally the total porosity was obtained from Equation 4.

$$
\begin{aligned}
& \rho_{v o l}=\frac{m_{d r} \times \rho}{m_{s a}-m_{f l}} \\
& \rho_{t r}=(\% \text { Chi } \times \rho \text { Chi })+(\% P V A \times \rho P V A)+(\% B G \times \rho B G) \\
& \text { Porosity }{ }_{\text {apparent }}(\%)=\frac{m_{s a}-m_{d r} \times 100}{m_{s a}-m_{f l}} \\
& \text { Total porosity }=\frac{\rho_{t r}-\rho_{v o l} \times 100}{\rho_{t r}}
\end{aligned}
$$

\subsubsection{Mechanical test}

The evaluation of scaffolds mechanical behavior was performed using the compression test equipment Universal Instron 5882 machine and a load cell of $5 \mathrm{kN}$ and test speed of $0.5 \mathrm{~mm} / \mathrm{min}$ at $22^{\circ} \mathrm{C}$ and according to ASTM D 695 (Standard Test Method for Compressive Properties of Rigid Plastics). The samples were in cylindrical shape with $18 \mathrm{~mm}$ diameter and $9 \mathrm{~mm}$ in height.

\subsubsection{Degradation test}

The degradation index (DI) was performed with samples in triplicate. The samples were dried by lyophilization and kept in vacuum desiccator for 48 hours to weight stabilization. The samples were weighed on an analytical balance and placed in containers containing simulated body fluid (SBF), according to the relationship between the surface area and the volume of solution equal to $0.1 \mathrm{~cm}^{-1}$.

The SBF was prepared according to ISO/FDIS 23317: 2007 (E), by dissolving $\mathrm{NaCl}$ (7.996 g), $\mathrm{NHCO}_{3}(0.350 \mathrm{~g}), \mathrm{KCl}(0.224 \mathrm{~g}), \mathrm{K}_{2} \mathrm{HPO}_{4} \cdot 3 \mathrm{H}_{2} \mathrm{O}(0.228 \mathrm{~g}), \mathrm{MgCl}_{2} \cdot 6 \mathrm{H}_{2} \mathrm{O}(0.305 \mathrm{~g}), \mathrm{CaCl}_{2}(0.228 \mathrm{~g})$ and $\mathrm{Na}_{2} \mathrm{SO}_{4}(0.071 \mathrm{~g})$, all supplied by Synth Brazil, in $1 \mathrm{~L}$ of distilled water. The solution was buffered ate $\mathrm{pH} 7.4$ adjusting the volume of trihydroxymethylaminomethane and $\mathrm{HCl}$ (Merck) at a temperature of $37^{\circ} \mathrm{C}\left( \pm 1^{\circ} \mathrm{C}\right)$. The containers with the samples were kept in a bath at $37^{\circ} \mathrm{C}\left( \pm 1^{\circ} \mathrm{C}\right)$. The degradation test was carried out in five periods $(0.5,2,12,24$ and 168 hours $)$. After that the samples were removed from the containers, rinsed thoroughly with deionized water and dried by lyophilization. Before being weighed samples remained in a 
vacuum desiccator for 48 hours. The DI was calculated according to Equation 5 where IDW is the initial dry weight and FSW is the final sample weight.

$D I=\frac{I D W-F S W \times 100}{\mathrm{IDW}}$

\subsection{Cytotoxicity Assay}

The cytotoxicity was measured by MTT assay [26]. Formazan crystals were solubilized and the optical density was determined by a spectrophotometer at $595 \mathrm{~nm}$. Primary culture of human fibroblasts cells at the fourth passage were plated in 24-well plates at a density of $1 \times 10^{4}$ cells/well. The cell populations were normalized with DMEM for 24 hours, after which time the medium was changed and the samples were placed in respective wells. The cylindrical samples were cut into four equal parts and were sterilized by irradiation at $15 \mathrm{kGy}$ for 30 minutes, half of the samples were soaked in saline solution (PBS) for 24 hours. DMEM, was used as experiment positive control and PBS 10x as a negative control. All assays were performed in triplicate $(\mathrm{n}=$ 3). The cells were incubated at $37^{\circ} \mathrm{C}$, humidified atmosphere of $5 \% \mathrm{CO}_{2}$ for 72 hours. At the end of this incubation period, the culture medium was removed and discarded and $210 \mu \mathrm{L} /$ well of DMEM was added. Then $170 \mu \mathrm{L} /$ well of MTT solution (Invitrogen) $\left(5 \mathrm{mg} / \mathrm{ml}\right.$ ) was added and the plate was incubated at $37^{\circ} \mathrm{C}$, humidified atmosphere of $5 \% \mathrm{CO}_{2}$ for 2 hours. The cells were observed under an optical microscope (MO) for displaying the formazan crystals that were solubilized by the addition of $210 \mu \mathrm{L} /$ well of a solution of SDS $10 \%$ $\mathrm{HCl}\left(0.01 \mathrm{M}\right.$ hydrochloric acid $-10 \%$ of sulphate sodium dodecyl water) followed by incubation at $37^{\circ} \mathrm{C}$, humidified atmosphere of $5 \% \mathrm{CO}_{2}$ for 18 hours. $100 \mu \mathrm{L}$ was transferred from each well to a 96 well plate, in triplicate, and the optical density was measured in a spectrophotometer at $595 \mathrm{~nm}$. All the steps were performed in minimal lighting conditions. The results were analyzed by One-way ANOVA followed by Bonferroni test and expressed as mean \pm SEM (standard error mean).

\section{RESULTS AND DISCUSSION}

\subsection{Morphology and pore structure}

The Chitosan/PVA/BG scaffolds showed final dimensions of 18x10mm, spongy consistency and homogeneous physical structure (Figure 1). The scaffolds pore morphology was analyzed by SEM and is shown in Figure 2, where it can be noted a network of well-defined, open and interconnected pores with thin walls. Overall, the pores located on the periphery of the scaffold showed a slight flattening on its surface, possibly caused by sample handling during the fracture to obtain the specimen, although fracture was conducted immersed in liquid nitrogen.
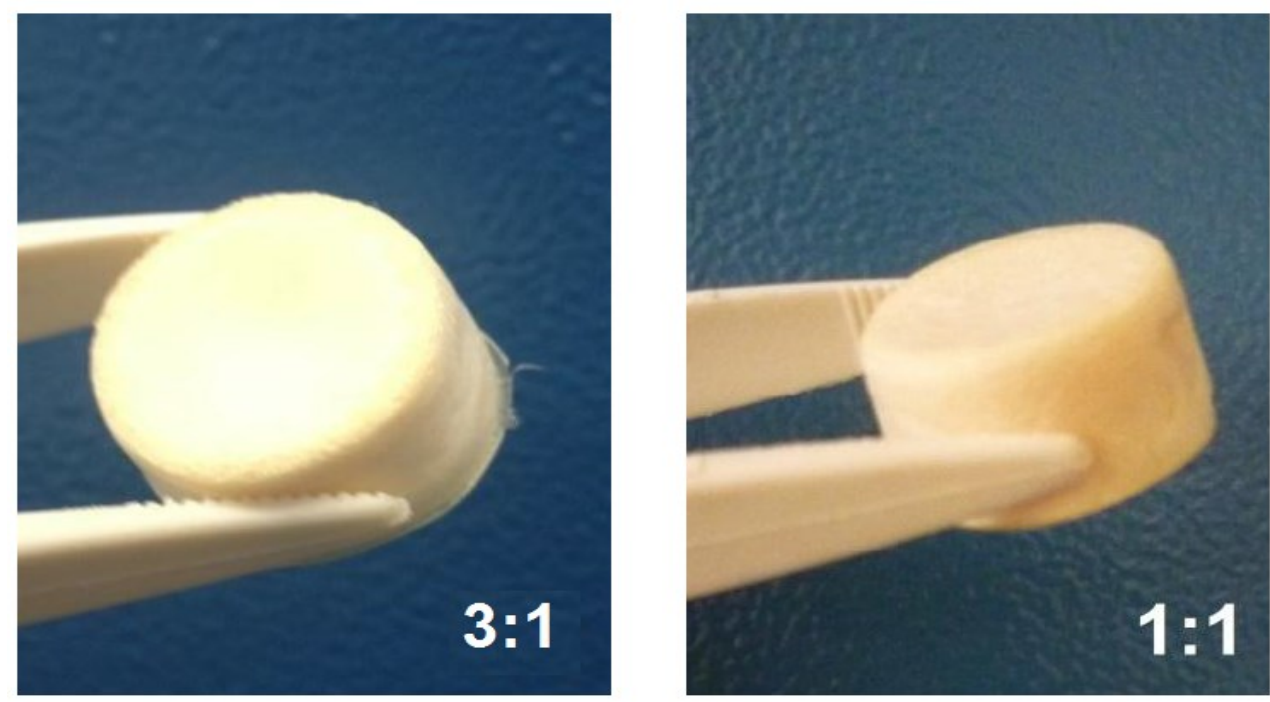

Figure 1: Structure of 3:1 and 1:1 scaffold successfully obtained with homogeneous and regular physical structure without cracks. 
It was observed homogeneous and organized porosity similar for the 1:1 and 3:1 scaffolds, although the first presented more uniform pores (Figure 3). The pore size in the regions analyzed ranged from 64 to $234 \mu \mathrm{m}$ in 1:1 scaffold, and 93 to $360 \mu \mathrm{m}$ in 3:1 scaffold. Both scaffolds presented satisfactory pore size range, and opened, interconnected pores (Figure 4), essential for tissue ingrowth according to the literature [27]. The presence of pores of different sizes is very important since bone tissue grows through interconnected pores in the range from 100 to $200 \mu \mathrm{m}$, while cell adhesion and vascular formation occurs in less than 100 $\mu \mathrm{m}$ pores.
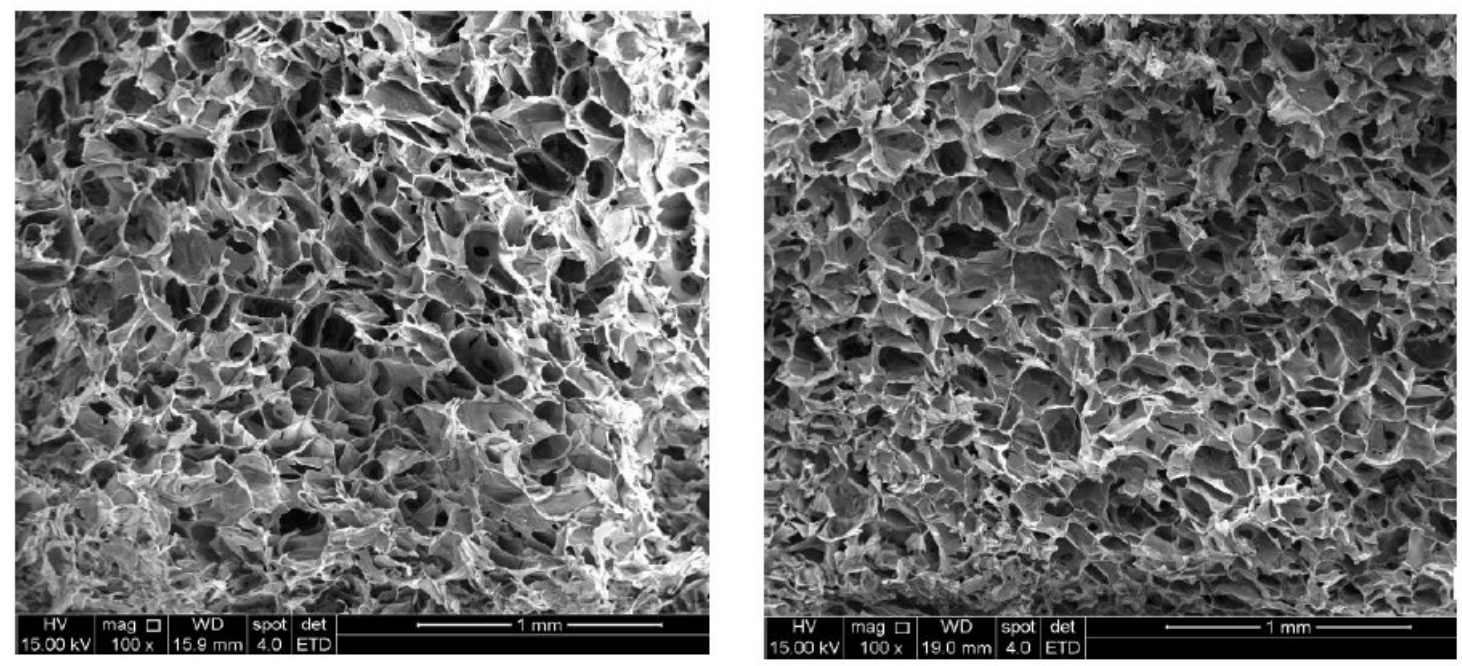

Figure 2: Chitosan/PVA/BG scaffolds SEM images (A) 3:1 and (B) 1:1 ratios.
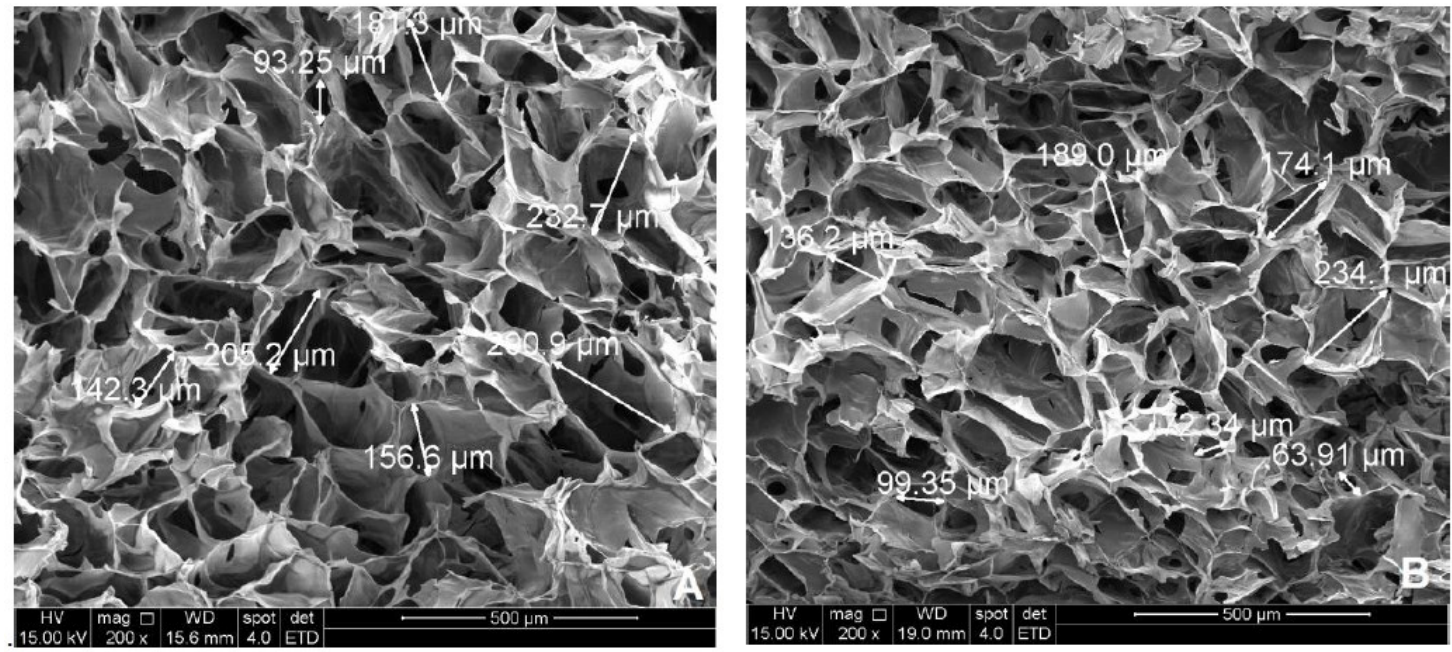

Figure 3: SEM images showing interconnected network pores with thin walls and uniform cavities. Chitosan/PVA/BG scaffolds (A) 3:1 and (B) 1:1 ratios. 

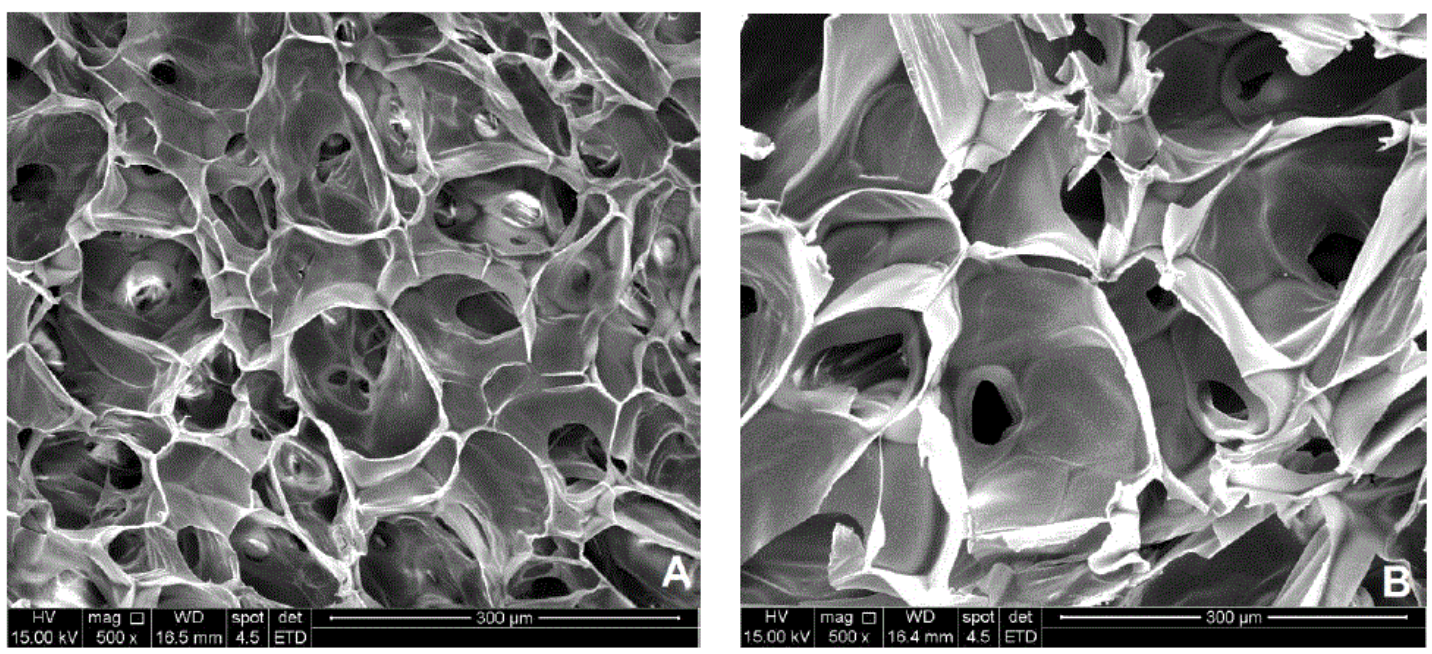

Figure 4: SEM images showing the pores architecture and interconnectivity of the 3:1 (A) and 1:1 (B) scaffolds.

\subsection{Fourier Transform Infrared Spectroscopy}

Figure 5 presents the FTIR spectra of the scaffolds normalized at the $1450 \mathrm{~cm}^{-1}$ band. The typical bands corresponding to both polymers in the blend are identified. It was observed by FTIR spectra characteristic peaks of amino group binding of Chitosan and broad and superimposed peaks associated with stretching vibration of Si-O-Si group on PVA $\left(1084 \mathrm{~cm}^{-1}\right)$ and Chitosan $\left(1029 \mathrm{~cm}^{-1}\right)$ chemical groups. The band at 966 $\mathrm{cm}^{-1}$ corresponds to Si-OH stretching. The shape of $1648 \mathrm{~cm}^{-1}$ band, associated with the imine bond $(\mathrm{C}=\mathrm{N})$, and $1558 \mathrm{~cm}^{-1}$ band, associated with the amino group $\left(\mathrm{NH}_{2}\right)$ are similar to that found by Costa-Jr. et al [21], and Monteiro Jr. [28]. The band at $1720 \mathrm{~cm}^{-1}$, related to free aldehyde groups (-COH) appears in the spectra of 3:1 scaffold. However, the spectrum on the 1:1 scaffold, this band does not appear, indicating a possible crosslinking with the amino group, forming the $\mathrm{C}=\mathrm{O}$ connection [22,29]. Dias et al. [30], identified in the FTIR spectrum of his work, the characteristic bands of PVA $\left(1084 \mathrm{~cm}^{-1}\right)$ and Chitosan $\left(1024 \mathrm{~cm}^{-1}\right)$ intensified by the presence of $\mathrm{BG}$ and the band $1644 \mathrm{~cm}^{-1}$, associated with the links of the $\mathrm{C}=\mathrm{N}$ imine (Schiff base) formed by the amino group of Chitosan with aldehyde group of glutaraldehyde. The presence of glutaraldehyde causes an increase in the intensity of band $1562 \mathrm{~cm}^{-1}$ associated with ethylenic bonds; and $2922 \mathrm{~cm}^{-1}$ frequency related to the stretching of $\mathrm{CH}$ groups. This fact can be attributed to increased contributions of glutaraldehyde molecule in quitosana-glutaraldehyde reaction that promotes the increase in crosslinking of the chain. The increasing intensity of the bands relating to the imine bond also suggests that GA crosslinking preferably occurs via Schiff base at carbon 2 glicossidic ring over the link with the hydroxyl groups on carbons 3 and 6 [22]. Ma et al. [31] reported that the potent cytotoxicity of glutaraldehyde can be reduced with the presence of Chitosan due to the large number of amino groups in its molecular chain, serving as a bridge, increasing the efficiency of crosslinking by glutaraldehyde. The band $1100 \mathrm{~cm}^{-1}$ is related to the glutaraldehyde crosslinking of the PVA, forming bridges acetals. The $1650 \mathrm{~cm}^{-1}$ and $1638 \mathrm{~cm}^{-1}$ bands are associated with the formation of the imine from the amine group of Chitosan during crosslinking by glutaraldehyde [32].

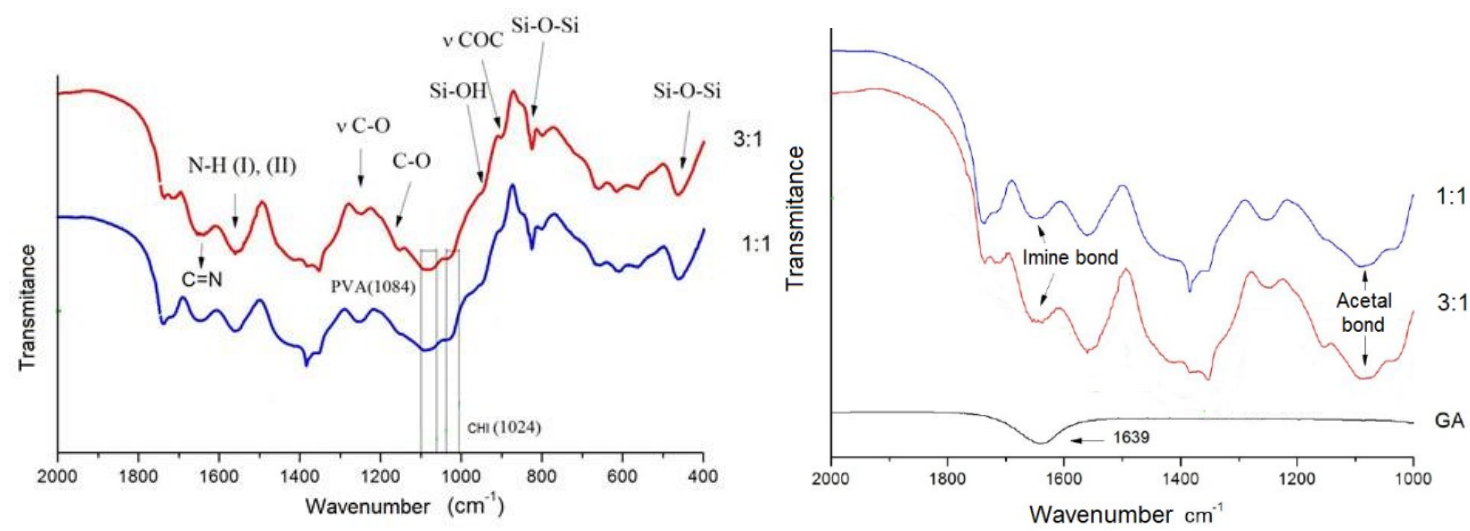

Figure 5: Normalized FTIR spectra of 1:1 and 3:1 scaffolds and glutaraldehyde (GA). 


\subsection{Porosity evaluation}

The results of porosity and density are presented in Table 2 . The matrices obtained showed high porosity as expected, both samples showing $97 \%$ total porosity. During the execution of the method, the matrix began to swell slightly as shown in Figure 6. To decrease the swelling effect on the measurements, the time of immersion in water was fixed as 20 minutes.

Table 2: Results obtained for porosity and density of scaffolds.

\begin{tabular}{c|c|c|c|c}
\hline Scaffold & $\mathbf{P}_{\text {apparent }}(\%)$ & $\mathbf{P}_{\text {total }}(\%)$ & $\boldsymbol{\rho}_{\text {vol }}\left(\mathbf{g} / \mathbf{c m}^{3}\right)$ & $\boldsymbol{\rho}_{\text {tr }}\left(\mathbf{g} / \mathbf{c m}^{3}\right)$ \\
\hline $3: 1$ & $50 \pm 5$ & $97.5 \pm 0.3$ & $0.04 \pm 0.02$ & 1.6 \\
\hline $1: 1$ & $56 \pm 3$ & $97.2 \pm 0.5$ & $0.04 \pm 0.01$ & 1.5 \\
\hline
\end{tabular}
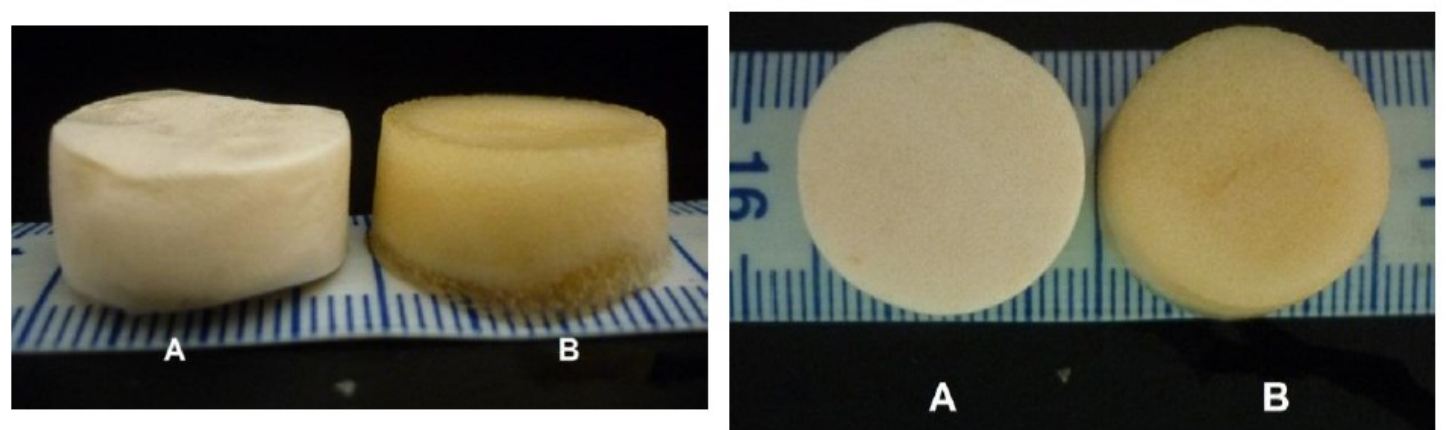

Figure 6: Representation of the swelling presented by 3:1 and 1:1 scaffolds before immersion in deionized water (A) and after 20 minutes immersion in deionized water (B) for the test of apparent porosity.

\subsection{Degradation test}

The hybrid matrices designed for tissue regeneration are expected to degrade at the same proportion that the regeneration of damaged tissue occurs. The most common signs that degradation is occurring are the mass loss and deterioration of the mechanical properties of the material [33]. Figure 7 shows the mass loss that occurred with time during the degradation test. Both scaffolds gained mass in the first 0.5 hour (3:1 gained $10.4 \%$ and $1: 1$ gained $14.0 \%$ ), possibly due to the formation of a carbonated hydroxyapatite layer on the surface of the scaffold.

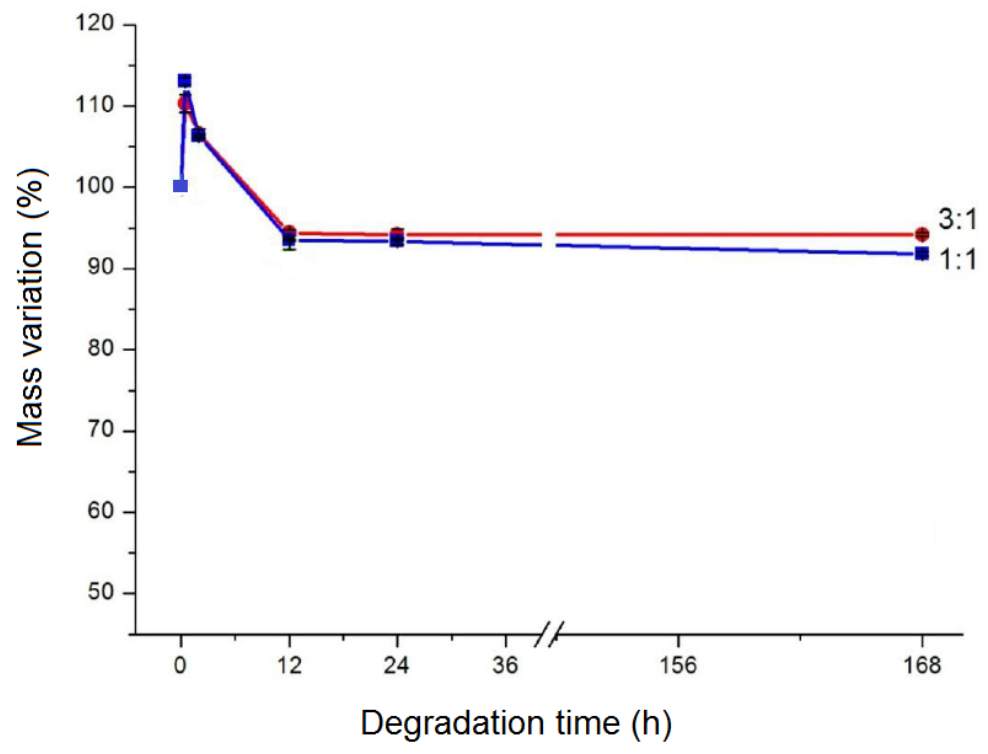

Figure 7: Mass loss upon immersion in SBF (simulated body fluid). 
The ratio of weight loss was very similar for the matrices $3: 1$ and $1: 1$. The mass loss presented by the matrices during the degradation test in vitro was around $10 \%$ after a week of testing, with macroscopic preservation of their physical structure. The mass loss was more intense for both scaffolds up to 12 hours. After this period, degradation of the matrices was quite slow. The degradation occurs probably by the solvation of ionic groups and by depolymerization of the polymer chains [23]. Degradation of the 3:1 scaffold was slightly lower than that of the 1:1; which can be explained by the preference of glutaraldehyde cross-linking of the amino group of Chitosan with the formation of the group $\mathrm{C}=\mathrm{N}$, rather than forming acetal bridge with PVA [23].

\subsection{Mechanical test}

The stress strain compression curves obtained from the compression test of 3:1 and 1:1 scaffolds are presented in Figure 8. A strain limit (around 63\%) was established to avoid damage of the equipment. The average elastic modulus resulted in values of 2.2 and $0.9 \mathrm{MPa}$ for 3:1 and 1:1 scaffolds respectively. Maximum stress supported at the strain limit established was 0.18 and $0.26 \mathrm{MPa}$, for $3: 1$ and $1: 1$ scaffolds respectively. The 3:1 scaffold showed higher modulus of elasticity and lower maximum stress in relation to $1: 1$, that is, the higher PVA content in the sample 1:1 compared to sample 3:1 affected differently these two properties. It should be pointed out that the toughness, as measured by the area under the stress-strain curve, is markedly higher for sample 1:1.

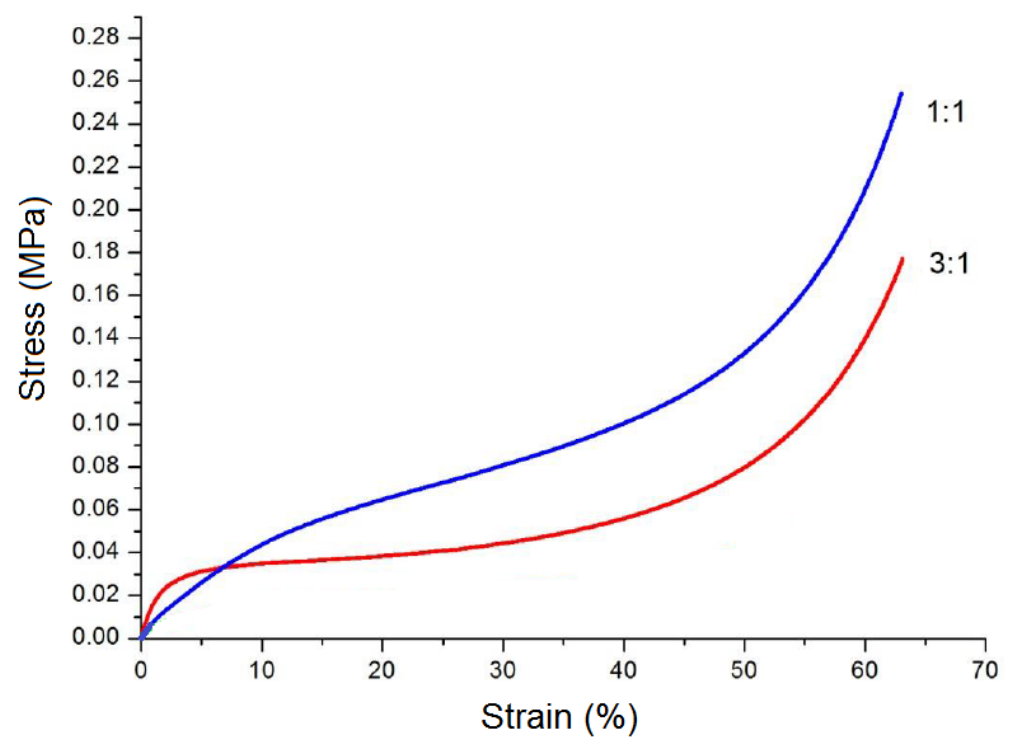

Figure 9: Stress strain compression curves for dried samples.

\subsection{Cytotoxicity}

The cytotoxicity assay aims to detect the potential of a material or device to produce lethal or sub lethal effects in biological systems at the cell level. This assay should be applied to all categories of biomaterials. The release of toxic sub products of the biomaterial can damage the cells or reduce the rate of cell culture growth. Compared to the positive control (human fibroblasts in culture medium) the cells cultured directly in presence of $1: 1$ and $3: 1$ scaffolds showed about $20 \%$ and $15 \%$ of viability respectively. This low viability is probably due to residual products inside the scaffolds pores. A biomaterial can be considered toxic to be used in biological systems under $50 \%$ of cell viability. However, when both scaffolds were soaked in PBS for 24 hours, the cells presented more than $90 \%$ of viability. The assay showed that both samples were toxic as produced and not toxic after treatment with PBS, showing this approach was suitable for neutralization of these samples.

\section{CONCLUSIONS}

The scaffolds obtained through the lyophilization route showed adequate pore structure, presenting about $97 \%$ porosity, pore size varying in the range $20-300 \mu \mathrm{m}$, and interconnected pores. The mass loss during the degradation test in vitro, was around $10 \%$ after a week of testing, with preservation of their macroscopic physical structure. The scaffolds obtained showed good deformation capacity but low compression strength. Cytotoxicity tests showed that the samples presented low cell viability before immersion in PBS. After im- 
mersion in PBS cell viability increased and was similar to control for both samples 1:1 and 3:1. Therefore, the 1:1 and 3:1 hybrids Chi/PVA with bioactive glass $20 \%(\mathrm{w} / \mathrm{w})$ cross-linked with glutaraldehyde and dried by lyophilization showed characteristics suitable for application in tissue engineering.

\section{ACKNOWLEDGEMENTS}

The authors gratefully acknowledge the financial support of CNPq, Capes and Fapemig.

\section{BIBLIOGRAPHY}

[1] AMINI, A.R., LAURENCIN, C.T., NUKAVARAPU, S.P., "Bone Tissue Engineering: Recent Advances and Challenges", Critical Reviews in Biomedical Engineering, v.40, pp. 363-408, 2012.

[2] ZOHORA, F.T., AZIM, A.Y.M.A., "Biomaterials as porous scaffolds for tissue engineering applications: a review”, European Scientific Journal, v.10, pp. 1857- 1881, 2014.

[3] CHEUNG, H.Y., LAU, K.T., LU, P.T., et al., "A critical review on polymer-based bio-engineered materials for scaffold development", Composites Part B - Engineering, v. 38, pp. 291-300, 2007.

[4] PETROVIC, V., ZIVKOVIC, P., et al., "Craniofacial bone tissue engineering”, Oral Surgery Oral Medicine, Oral Pathology Oral Radiology, v.114, pp. e1-e9, 2012.

[5] MOTA, J., YU, N., CARIDADE, S.G., et al., "Chitosan/bioactive glass nanoparticle composite membranes for periodontal regeneration," Acta Biomaterialia, v. 8, n. 11, pp. 4173-4180, 2012.

[6] HOKUGO, A., TAKAMOTO, T., TABATA,Y., "Preparation of hybrid scaffold from fibrin and biodegradable polymer fiber", Biomaterials, v.27, pp. 61-67, 2006.

[7] JONES,J.R.,"Reprint of: Review of bioactive glass: From Hench to hybrids", Acta Biomater., v.23, pp.53-82, 2015.

[8] RAHAMAN, M.N, DAY, D.E., SONNY BAL, B., et al, "Bioactive glass in tissue engineering", Acta Biomater., v.7, pp.2355-2373, 2011.

[9] DUTRA, C.E.A., PEREIRA, M.M., SERAKIDES, R., et al., "In vivo evaluation of bioactive glass foams associated with platelet-rich plasma in bone defects", Journal of Tissue Engineering and Regenerative Medicine, v.2, pp.221-227, 2008.

[10] PEREIRA, M. M., JONES, J. R, OREFICE, R. L, et al., "Preparation of Bioactive Glass-Polyvinyl Alcohol Hybrid Foams by the Sol-Gel Method", Journal of Materials Science. Materials in Medicine, v.16, pp.1045 - 1050, 2005.

[11] REZWAN, K., CHEN, Q.Z., BLAKER, J.J., et al., "Biodegradable and bioactive porous polymer/inorganic composite scaffolds for bone tissue engineering", Biomaterials, v. 27, pp. 3413-3431, 2006.

[12] WANG, Y., YANG, C., X. CHEN, X., et al., "Development and characterization of novel biomimetic composite scaffolds based on bioglass-collagen-hyaluronic acid-phosphatidylserine for tissue engineering applications", Macromolecular Materials and Engineering, v.291, pp. 254-262, 2006.

[13] RODRIGUES, C.V.M., SERRICELLA, P., LINHARES, A.B.R., et al., "Characterization of a bovine collagen-hydroxyapatite composite scaffold for bone tissue engineering”, Biomaterials, v. 24, pp. 4987-4997, 2003.

[14] LEVENGOOD, S.K.L. and ZHANG, M.Q., "Chitosan-based scaffolds for bone tissue engineering", Journal of Materials Chemistry B, v. 2, pp. 3161-3184, 2014.

[15] CROISIER, F. and JÉRÔME, C., "Chitosan-based biomaterials for tissue engineering", European Polymer Journal, v. 49, pp. 780-792, 2013.

[16] NANDI, S.K., KUNDU, B. and BASU, D., "Protein growth factors loaded highly porous chitosan scaffold: a comparison of bone healing properties", Materials Science and Engineering C, v. 33, pp. 1267-1275, 2013.

[17] MAJI, K., DASGUPTA, S., PRAMANIK, K., et al., "Preparation and Evaluation of Gelatin-ChitosanNanobioglass 3D Porous Scaffold for Bone Tissue Engineering", International Journal of Biomaterials, v.2016, Article ID 9825659, pp.1-14, 2016.

[18] MARTINO, A.D., SITTINGER, M., RISBUD, M.V., "Chitosan: a versatile biopolymer for orthopaedic tissue-engineering", Biomaterials, v. 26, pp. 5983-5990, 2005.

[19] ZHANG, Y., NI, M., ZHANG, M., RATNER, B., "Calcium phosphate-chitosan composite scaffolds for bone tissue engineering", Tissue Eng., v. 9, pp. 337-45, 2003. 
[20] LEMOS, E.M.F. , PATRICIO, P.S., DONICCI, C.L., et al, "Comparison of the Effect of Sol-Gel and Coprecipitation Routes on the Properties and Behavior of Nanocomposite Chitosan-Bioactive Glass Membranes for Bone Tissue Engineering", Journal of Nanomaterials , v. 2015, p. 1-8, 2015.

[21] COSTA-JUNIOR, E. S., MANSUR, H.S. "Preparação e caracterização de blendas de quitosana/ poli(álcool vinílico) reticuladas quimicamente com glutaraldeído para aplicação em engenharia de tecido", Química Nova, v. 31, n. 6, p. 1460- 1466, 2008.

[22] COSTA-JUNIOR, E. S., PEREIRA, M. M., MANSUR, H. S., "Properties and biocompatibility of Chitosan films modified by blending with PVA and chemically crosslinked", Journal of Materials Science: Materials in Medicine, v. 20, pp. 553- 561, 2009.

[23] COSTA-JÚNIOR, E.S., PEREIRA, M.M., MANSUR, H.S., "Properties and biocompatibility of chitosan films modified by blending with PVA and chemically crosslinked", Journal of Materials Science. Materials in Medicine, v. 20, pp. 553-561, 2009.

[24] O'BRIEN, F.J., HARLEY, B.A., YANNAS, I.V., et al., "Influence of freezing rate on pore structure in freeze-dried collagen-GAG scaffolds", Biomaterials, v. 25, pp. 1077-1086, 2004.

[25] JENNINGS, T.A., Lyophilization Introduction and Basic Principles., CRC Press, Florida, 1999.

[26] MOSMANN, T. Rapid Colorimetric Assay for Cellular Growth and Survival: Application to Proliferation and Cytotoxicity Assays, Journal of lmmunological Methods, v. 65, pp. 55-63, 1983.

[27] MIZUNO, K., KIDO, H., NARITA, T., et al., "Control of degradation rate of porous biodegradable polymers., In: Proceedings of the 8th polymer for advanced technologies international symposium, pp. 13-16, Budapest, Hungary, 2005.

[28] MONTEIRO JR., O. A. C., AIROLDI, C., "Some studies of crosslinking Chitosan-glutaraldehyde interaction in a homogeneous system", International Journal of Biological Macromolecules, v 26, n. 2-3, pp. 119- 128, 1999.

[29] MANSUR, H. S., COSTA, H. S., "Nanostructured poly(vinyl alcohol)/bioactive glass and poly (vinyl alcohol)/Chitosan/bioactive glass hybrid scaffolds for biomedical applications", Chemical Engineering Journal, v. 137, p. 72-83, 2008.

[30] DIAS, S.L., MANSUR, H.S., DONNICI, C.L., et al., "Synthesis and characterization of chitosanpolyvinyl alcohol-bioactive glass hybrid membranes", Biomatter, v. 1, pp. 114-119, 2011.

[31] MA, L., GAO, C., MAO, Z., et al., "Collagen/Chitosan porous scaffolds with improved biostability for skin tissue engineering", Biomaterials, v. 24, pp. 4833-4841, 2003.

[32] RAO, P. S., SMITHA, B., SRIDHAR, S., et al., "Preparation and performance of poly(vinyl alcohol)/polyethyleneimine blend membranes for the dehydration of 1,4-dioxane by pervaporation: Comparison with glutaraldehyde cross-linked membranes", Separation and purification Technology, v. 48, n. 3, p. 244254, 2006.

[33] COSTA, H.S., MANSUR, A.A.P., PEREIRA, M.M., et al., "Engineered Hybrid Scaffolds of Poly(vinyl alcohol/Bioactive Glass for Potential Bone Engineering Applications: Synthesis, Characterization, Cytocompatibility, and Degradation", J. Nanomater, v. 2012, p. 1-16, 2012. 